Research Paper

\title{
The Evaluation of the Distribution of Yeast like Fungi 'Candida Species' at a Tertiary Care Center in Western Turkey
}

\author{
Gulfem Ece ${ }^{凶}$, Pinar Samlioglu, Gulgun Akkoclu, Sabri Atalay, Sukran Kose \\ Tepecik Education and Research Hospital Department of Infectious Diseases and Clinical Microbiology, Izmir/Turkey
}

$\triangle$ Corresponding author: Dr. Gulfem Ece, Tepecik Education and Research Hospital Department of Infectious Diseases and Clinical Microbiology Gaziler Caddesi No:468 35120 Yenisehir Konak/Izmir/Turkey. Fax number: +902324330756. E- mail: gulfem.ece@izmir.edu.tr, gulfem.ece@gmail.com . Tel: +902324696969 Mobile:+905322731711

( ) Ivyspring International Publisher. This is an open-access article distributed under the terms of the Creative Commons License (http://creativecommons.org/ licenses/by-nc-nd/3.0/). Reproduction is permitted for personal, noncommercial use, provided that the article is in whole, unmodified, and properly cited.

Received: 2012.06.08; Accepted: 2012.09.09; Published: 2012.09.19

\begin{abstract}
Objective: Candida infections have increased due to transplant patients, prolonged ICU stay and invasive procedures. The most common isolated strain is $C$. albicans. The aim of this study was to evaluate the distribution of Candida isolates at Tepecik Education and Research Hospital.

Materials and Methods: Yeast like fungi were isolated between I3.01.2010 and 19.08.20I I at Mycology Laboratory. The identification was done by conventional methods and carbohydrate assimilation profile using the ID32C identification system (Biomerieux, France).

Results: Yeast like fungi were isolated from 337 clinical specimens. They consisted of urine, blood culture, respiratory specimen and wound. The most isolated yeast strains were C.albicans (38.6\%), C.tropicalis (13.9\%), C. parapsilosis (28.4\%), C.glabrata (7.4\%), C.krusei (3.8\%).

Conclusion: Recently there is an increment in Candida infections. In this study the most common strain was C.albicans and the rate $C$. glabrata and $C$. krusei isolates were lower than expected. C. parapsilosis was the most isolated strain in blood cultures and this may be due to invasive procedures and the use of indwelling catheters.
\end{abstract}

Key words: Candida species, Candida infection, species distribution, yeast like fungi

\section{Introduction}

Infections caused by opportunistic pathogens, such as yeasts, are becoming important reasons of morbidity and mortality because of alterations in the immune system and invasive hospital procedures (1). AIDS, organ transplantation, chemotherapy, invasive procedures and radiotherapy increased the prevalence of immunocompromised individuals and also diabetes mellitus, and the over use of extended spectrum antibiotics made an increment in these infections (2-4).

Infections due to yeast like fungi increase at intensive care units (5). In the last two decades nosocomial fungal infections increased all around the world. Yeast like fungi are the fourth agent in the blood stream infections. C. albicans, C.tropicalis and C. parapsilosis are the most common yeast like fungi causing blood stream infection (6). The aim of our study was to evaluate the distribution of yeast like fungi isolated from clinical specimens at Tepecik Education and Research Hospital Infectious Diseases and Clinical Microbiology Department Mycology Laboratory which was recently opened.

\section{Materials and Methods}

Yeast like fungi were isolated from the various clinical specimens (wound, urine, blood, respiratory 
specimen) between 13.01.2010 and 19.08.2011 at Tepecik Education and Research Hospital Infectious Diseases and Clinical Microbiology Department Mycology Laboratory. Each isolate belonged to a single patient. All the isolates were identified to species level by the germ tube test, Chrom Agar Candida (Salubris, Istanbul,Turkey), Cornmeal Tween 80 medium (Salubris, Istanbul, Turkey) and carbohydrate assimilation profile using the ID32C yeast identification system (Biomerieux, France).

\section{Results}

Yeast like fungi were isolated from 337 clinical specimens. These samples were received from Inten- sive Care Units (ICUs), Pediatrics, Internal Medicine, Infectious Diseases and Clinical Microbiology, Urology and Ear Nose Throat Departments. The specimens consisted of 144 urine (42.7\%), 155 blood culture $(45.9 \%), 13(3.8 \%)$ respiratory specimen and 25 $(7.4 \%)^{\prime}$ wound. The isolated yeast strains were 130 (38.6\%) C.albicans, 47 (13.9\%) C.tropicalis, 96 (28.4\%)C. parapsilosis, 25 (7.4\%) C.glabrata, 13 (3.8\%) C.krusei, 10 (2.9\%) C.kefyr, four (1.2\%) C. guillermondii, five (1.5\%) C. pelliculosa, four $(1.2 \%)$ C.dubluniensis, two $(0.6 \%)$ C. famata, and one (\%0.3) C. lusitaniae. The distribution of yeast like fungi acoording to specimen type and various departments were shown in Table 1 and Table 2.

Table I: Distribution of yeast like fungi according to various clinical departments of the hospital

\begin{tabular}{|c|c|c|c|c|c|c|c|c|c|c|c|}
\hline & C.albicans & C.tropicalis & C.parapsilosis & C.glabrata & C.kefyr & $\begin{array}{c}\text { C.guiller } \\
\text { mondii }\end{array}$ & C.krusei & $\begin{array}{c}\text { C. pel- } \\
\text { liculosa }\end{array}$ & $\begin{array}{c}\text { C.dublinie } \\
\text { nsis }\end{array}$ & C. famata & $\begin{array}{c}\text { C.lusitani } \\
a e\end{array}$ \\
\hline $\begin{array}{l}\text { Anesthesi- } \\
\text { ology In- } \\
\text { tensive } \\
\text { care unit }\end{array}$ & $26(7.7 \%)$ & $5(1.48 \%)$ & $34(\% 10.1)$ & $8(2.37 \%)$ & & & & & $3(0.89 \%)$ & $1(0.29 \%)$ & \\
\hline $\begin{array}{l}\text { Pediatrics } \\
\text { ICU }\end{array}$ & $5(1.48 \%)$ & & $12(3.56 \%)$ & & $1(0.29 \%)$ & & & & & & \\
\hline $\begin{array}{l}\text { Internal } \\
\text { Medicine } \\
\text { ICU }\end{array}$ & $19(5.6 \%)$ & $3(0.89 \%)$ & $4(1.2 \%)$ & $5(1.48 \%)$ & $1(0.29 \%)$ & & $6(1.78 \%)$ & & & $1(0.29 \%)$ & \\
\hline $\begin{array}{l}\text { Neurology } \\
\text { ICU }\end{array}$ & $4(1.2 \%)$ & $3(0.89 \%)$ & $5(1.48 \%)$ & $1(0.29 \%)$ & & $1(0.29 \%)$ & & & & & \\
\hline Surgery & $7(2.1 \%)$ & & $3(0.89 \%)$ & & & & $2(0.59 \%)$ & & & & \\
\hline Pediatrics & $35(10.3 \%)$ & $12(3.56 \%)$ & $19(5.6 \%)$ & & & $1(0.29 \%)$ & $2(0.59 \%)$ & & & & \\
\hline $\begin{array}{l}\text { Internal } \\
\text { Medicine }\end{array}$ & 18 & $3(0.89 \%)$ & $4(1.2 \%)$ & $4(1.2 \%)$ & $1(0.29 \%)$ & & $1(0.29 \%)$ & & & & \\
\hline $\begin{array}{l}\text { Infectious } \\
\text { diseases }\end{array}$ & $7(2.1 \%)$ & & $4(1.2 \%)$ & $4(1.2 \%)$ & $2(0.59 \%)$ & & $1(0.29 \%)$ & & & & $1(0.29 \%)$ \\
\hline Eye & & $1(0.29 \%)$ & & & & & & & & & \\
\hline Urology & $5(1.48 \%)$ & $19(5.6 \%)$ & $10(2.9 \%)$ & $3(0.89 \%)$ & $2(0.59 \%)$ & $2(0.59 \%)$ & & $5(1.48 \%)$ & $1(0.29 \%)$ & & \\
\hline $\begin{array}{l}\text { Ear, Nose, } \\
\text { Throat }\end{array}$ & $1(0.29 \%)$ & & & & & & & & & & \\
\hline Neurology & & $1(0.29 \%)$ & $1(0.29 \%)$ & & & & & & & & \\
\hline $\begin{array}{l}\text { Organ } \\
\text { Trans- } \\
\text { plantation }\end{array}$ & $3(0.89 \%)$ & & & & $3(0.89 \%)$ & & $1(0.29 \%)$ & & & & \\
\hline
\end{tabular}

Table 2: The distribution of yeast like fungi according to specimen type

\begin{tabular}{|l|l|l|l|l|l|l|l|l|l|l|l|l|}
\hline & C.albicans & C.tropicalis & C.parapsilosis & C.glabrata & C.kefyr & $\begin{array}{c}\text { C.guillerm } \\
\text { ondii }\end{array}$ & C.krusei & C.pelliculosa & C.dubliensis & C. famata & C.lusitaniae \\
\hline $\begin{array}{l}\text { Blood } \\
\text { culture }\end{array}$ & $39(11.5 \%)$ & $20(5.9 \%)$ & $75(22.2 \%)$ & $6(1.78 \%)$ & & $1(0.29 \%)$ & $7(2.1 \%)$ & $5(1.48 \%)$ & $2(0.59 \%)$ & & \\
\hline Wound & $8(2.37 \%)$ & $3(0.89 \%)$ & $11(3.26 \%)$ & & $1(0.29 \%)$ & & $2(0.59 \%)$ & & & \\
\hline Urine & $73(21.6 \%)$ & $23(6.8 \%)$ & $10(2.9 \%)$ & $19(5.63 \%)$ & $9(2.67 \%)$ & $3(0.89 \%)$ & $4(1.19 \%)$ & & $1(0.29 \%)$ & $1(0.29 \%)$ & $1(0.29 \%)$ \\
\hline $\begin{array}{l}\text { Respira- } \\
\text { tory } \\
\text { Specimen }\end{array}$ & $10(2.9 \%)$ & $1(0.29 \%)$ & & & & & & & $1(0.29 \%)$ & $1(0.29 \%)$ & \\
\hline
\end{tabular}




\section{Discussion}

Candida are prevalent all around the world and cause infectios within a spectrum of noninvasive infections to invasive opportunistic infections. Endogeneous infections are because of Candida existing in the normal human flora. Exogeneous infections are due to hands of hospital staff, contaminated biomaterials and catheters $(7,8)$. Hematologic disorders, immunosuppresive therapy, bone marrow transfer, organ transplantation, use of extended spectrum antibiotics, radiotherapy, burns, and longer duration in intensive care units are the main risk factors (9).

Otag et al. investigated the yeast like fungi isolated from clinical specimens between August 2003-2005 at Mersin University Hospital Microbiology Laboratory. 872 yeast like fungal strains from 471 patients and 811 clinical specimens were taken into the study. C. albicans was the most common yeast like fungi isolated in all clinical specimens and C. parapsilosis $(51.8 \%)$ was the one in blood culture strains. The highest increase was in C. parapsilosis isolates over the time. The increment was similar between C. albicans and C. glabrata strains. There was a decrease in $C$. tropicalis. C. albicans was the most common isolated strain overall; but there is a increase in non C. albicans especially in intensive care units (10).

Ergon et al. investigated 390 fungi like yeast isolated from intensive care units over a four year period. Blood culture, tracheal aspirate and urine were the most common specimens and C.albicans was $53.3 \%, C$. tropicalis $14.5 \%$, C. glabrata $12.2 \%$ and C. parapsilosis $6.5 \%$.detected. According to the authors C. albicans was the most common isolated strain and an increase in non albicans isolates such as C. glabrata and $C$. tropicalis was detected (11).

Kuzucu et al. evaluated the blood culture of twenty patients in one year period and the most common isolated strain was C. albicans (12). In our study the most frequently isolated strain from blood cultures was C.parapsilosis and C.albicans was in second place.

Gultekin et al. investigated the seven year period between January 2003- December 2009 for blood culture isolates. A total of 24709 blood cultures were obtained from 119 patients. 119 (0.48\%) samples yielded Candida species. These consisted of C.albicans (49\%), C. parapsilosis (23\%), C. tropicalis (14\%), C. glabrata (12\%), one C.guillermondii and one C. krusei. According to the authors the most common isolated strain was C. albicans and the most prevalent non $C$. albicans isolates were $C$. parapsilosis and C. tropicalis. They also think that when considering candidemias, studies evaluating predisposing factors should be held in order to decrease morbidity and mortality and also to take the preventive measures (13).

Kocoglu et al. investigated the distribution and the antifungal susceptibility of yeast like fungi at Gaziantep University Hospital Mycology Laboratory from various clincal specimen in an one year period. The most common one was C.albicans $(56.8 \%)$, secondly C.tropicalis $(7.7 \%)$ and thirdly C. sake $(6.8 \%)$. C.parapsilosis was the second most common isolated strain in blood culture specimens (14).

Asticcoli et al. evaluated the newborn candidosis cases at the newborn intensive care unit between August 2005-January 2006 in Italy. Twenty two cases were investigated and the clonal spread of $C$. albicans isolates were shown (15).

Motta et al. investigated the distribution and the antifungal susceptibility of yeast like fungi isolated from blood cultures at a tertiary education hospital in Brazil in 2006. The isolated yeast like fungi were C.albicans $(52.2 \%)$, C. parapsilosis $(22.1 \%)$, C. tropicalis $(14.8 \%)$ and C. glabrata (6.6\%), respectively. According to the authors candidemia incidence is high and the distribution of Candida species and their antifungal susceptibility should be known (16).

Dimopoulos et al. evaluated the candidemia cases that took place after hospitalization at ICU. 1037 admission and 56 candidemias between January 2001-December 2005 were examined. $64.3 \%$ of the cases were C. albicans and $35.7 \%$ were non C. albicans (17).

Badiee et al. investigated the mucosal Candida colonisation in 273 HIV seropositive patients in a two year period in Iran. 273 oral and 86 vaginal specimens were examined. Among these $50 \%$ C. albicans was isolated and this was followed by C. glabrata $(21.4 \%)$, C. dubliniensis (13.3\%), C. krusei (9.8\%), C. kefyr (3.1\%), C. parapsilosis $(1.6 \%)$ and C. tropicalis $(0.8 \%)(18)$.

Mokaddas et al. investigated the ditribution and antifungal susceptibility of yeast like fungi isolated from blood culures during a ten year period in Mycology Reference Laboratory in Kuwait. The species identification was done by germ tube test and auotmatized Vitek 2 system. C. albicans (39.5\%) was the predominant strain and followed by C. parapsilosis, $C$. albicans and C. krusei. C. albicans, C. albicans, C.tropicalis and C. glabrata were all susceptible to amphotericin B. C. parapsilosis isolates were $2 \%$ resistant to amphotericin B. Nine C. albicans strains were resistant to fluconazole. The authors think that the data in this study is similar to various other studies. Although there is over use of fluconazole ve amphotericin B in clinical practice, there is not an increase in resistance rate (19).

Recently there is an increase in invasive infections caused by Candida due to immunsuppresive 
individuals, patients with organ transplantation and hospitalization at ICUs. In this study, isolated yeast strains were $130 \quad(38.6 \%) \quad$ C.albicans, $47 \quad(13.9 \%)$ C.tropicalis, $96 \quad(28.4 \%) \quad$ C.parapsilosis, $25 \quad(7.4 \%)$ C.glabrata, 13 (3.8\%) C.krusei, 10 (2.9\%) C.kefyr, four $(1.2 \%)$ C. guillermondii, five (1.5\%) C. pelliculosa, two $(0.6 \%)$ C. famata, one $(\% \quad 0.3)$ C. lusitaniae and four $(1.2 \%)$ C.dubluniensis. In our study the most common isolated strain was C. albicans and this is similar to most of the studies stated above. C. parapsilosis was the most isolated strain in blood cultures and this may be due to invasive procedures and the use of catheters. Five C.pelliculosa isolates were identified from blood culture at the same department and this may indicate nosocomial infection due to application of invasive procedures in that unit. The prevalence of non albicans isolates C. glabrata and C. krusei were low. Because of this situation azolles could be a choice in antifungal treatment. Since our Mycology Laboratory has been recently developed, the greater number of received samples and identified Candida species will help us to monitor and choose appropriate antifungal treatment at our hospital in the future.

\section{Competing Interests}

The authors have declared that no competing interest exists.

\section{References}

1. White, TC, Marr KA, Bowden RA. Clinical, cellular, and molecular factors that contribute to antifungal drug resistance. Clin Microbiol Rev.1998; 11(2):382-402.

2. Fridkin SK, Jarvis WR. Epidemiology of nosocomial fungal infections. Clin Microbiol Rev. 1996; 9(4):499-511.

3. Adiloglu AK, Sirin MC, Cicioglu-Arıdoğan C, et al. Çeşitli klinik örneklerden izole edilen Candida kökenlerinin identifikasyonu ve antifungal duyarlılıklarının araştırılması. Journal of Adnan Menderes University Medical Faculty. 2004; 5(3):33-36.

4. Fernandes R, Viegas A, Cerquira F. Candida species distribution in clinical samples. Revista da Faculda de Ciencias da Saude. 2009; 6: 264-271.

5. Yenisehirli G, Bulut Y, Gunday E. Yoğun Bakım Ünitesinde yatan hastaların kan kültürlerinden izole edilen Candida albicans suşlarında antifungallere duyarlılık. ANKEM Dergisi. 2007; 21(3):146-149.

6. Bruder-Nascimento A, Camargo $\mathrm{CH}$, Sugizaki MF, et al. Species distribution and susceptibility profile of Candida species in a Brazilian public tertiary hospital. BMC Research Notes 2010; 3:1.

7. Diekema DJ, Pfaller MA. Nosocomial candidemia: an ounce of prevention is beter than a pound of cure. Infect Control Hosp Epidemiol. 2004; 25(8):624-6.

8. Pfaller MA, Diekema DJ. Epidemiology of invasive candidiasis: a Persistent public health problem. Clin Microbiol Rev. 2007; 20(1): 133-163.

9. Arıkan Akdağlı S. İnvazif Mantar İnfeksiyonlarının Epidemiyolojisi: Nereden Nereye. ANKEM Dergisi. 2010; 24(Ek 2):132-134.

10. Otag F, Aslan G, Sen S, et al. 2003-2005 süresinde klinik örneklerden izole edilen maya türlerinin değerlendirilmesi. Infeksiyon Dergisi 2005;19 (4): 435-443.

11. Ergon MC, Yucesoy M. Evaluation of species distribution of yeasts isolated from intensive care units during the four years period. Mikrobiyol Bul. 2005;39(3):309-18.

12. Kuzucu C, Yetkin G, Çalışkan A. Bir yıl içerisinde kan kültürlerinden izole edilen Candida türlerinin dağılımı ve antifungal duyarlılıkları. Erciyes Tıp Dergisi 2007;29(2):115-119.

13. Gultekin B, Eyigor M, Telli M, et al. Yedi Yıllık Dönemde Kan Kültürlerinden izole edilen Candida türlerinin retrospektif olarak incelenmesi. ANKEM Dergisi. 2010; 24(4):202-208.
14. Koçoglu E, Bayram A, Balcı I. Klinik orneklerden izole edilen Candida Türleri ve Antifungal Duyarlılıkları. Van Tıp Dergisi. 2005; 12 (3):195-200.

15. Asticcioli S, Nucleo E, Perotti G, et al. Candida albicans in a neonatal intensive care unit: antifungal susceptibility and genotypic analysis. New Microbiol 2007;30(3):303-7.

16. Motta AL, Duboc de Almeida GM, de Almeida Júnior JN, et al. Candidemia epidemiology and susceptibility profile in the largest Brazilian teaching hospital complex. Braz J Infect Dis. 2010;14(5):441-8.

17. Dimopoulos G, Ntziora F, Rachiotis G, et al. Candida albicans Versus Non-Albicans Intensive Care Unit-Acquired Bloodstream Infections: Differences in Risk Factors and Outcome. Anesth Analg. 2008;106(2):523-9.

18. Badiee P, Alborzi A, Davarpanah MA, et al. Distributions and Antifungal Susceptibility of Candida Species from Mucosal Sites in HIV Positive Patients. Arch Iran Med. 2010; 13(4):282-287.

19. Mokaddas EM, Al-Sweih NA, Khan ZU. Species distribution and antifungal susceptibility of Candida bloodstream isolates in Kuwait: a 10-year Study. J Med Microbiol; 2007;56(Pt2): 255-259. 